\title{
A relevância das metáforas como conceitualização das experiências: uma reflexão sobre o ensino/aprendizagem de inglês no ensino regular
}

\author{
Gabriela da Cunha Barbosa Saldanha*
}

\begin{abstract}
Resumo
Concebendo a metáfora como um meio de conceitualização do mundo a partir de nossas experiências cotidianas, o presente estudo tem como objetivo central identificar as metáforas de estudantes do ensino médio acerca de sua aprendizagem de inglês no ensino fundamental. A pesquisa, realizada em agosto de 2015, apresenta uma natureza mista, utilizando dados qualitativos e quantitativos. A análise do corpus se apoiou nos pressupostos da Teoria da Metáfora Conceitual, em trabalhos já realizados por autores renomados nesse campo, bem como no marco de referência de experiências. Os resultados revelam que, apesar de haver um número maior de metáforas sobre experiências de insucesso relativas à aprendizagem e ao professor, também foram identificadas metáforas acerca de experiências bem-sucedidas, o que demonstra um rompimento com a lógica do "inglês de colégio" e corrobora a tese de que é possível, sim, aprender inglês na escola regular.
\end{abstract}

Palavras-chave: Metáforas. Experiências. Ensino/aprendizagem de inglês. Escola regular.

\section{Introdução}

A análise metafórica configura-se como uma "excelente ferramenta metodológica" (GOMES JUNIOR, 2011, p. 18), para acessar os conceitos dos aprendizes acerca de sua aprendizagem de inglês, em que se prioriza a análise indireta a partir da formulação de metáforas. E é diante delas que o pesquisador poderá, indutivamente, perceber como os aprendizes vislumbram esse processo.

Pesquisas acerca de metáforas na linguística aplicada (KRAMSCH, 2003; CAMERON, 1999; CORTAZZI; JIN, 1999) evidenciam que as metáforas produzidas por aprendizes são ótimos veículos para deixar claras suas ideias e

1 Doutoranda em Estudos Linguísticos (Linguística Aplicada) - UFMG/ Bolsista CNPq. 
concepções. Sendo assim, "analisar metáforas seria como encarar o processo de aprendizagem pela perspectiva do participante" (GOMES JUNIOR, 2011, p. 18). Além disso, uma vez que partimos do princípio de que os linguistas aplicados se preocupam com "o uso da linguagem em situações reais da vida, particularmente aquelas consideradas problemáticas" (CAMERON, 1999, p. 3), ${ }^{1}$ concordamos que, no campo da linguística aplicada, pesquisas que exploram metáforas têm como foco "revelar e entender os processos que subjazem à aprendizagem da linguagem e seu uso, e, talvez por meio dela, propor conclusões e/ou hipóteses" (CAMERON, 1999, p. 3). ${ }^{2}$

É interessante ressaltar que, como a metáfora é um meio de se conceitualizar o mundo a partir das nossas experiências cotidianas (LAKOFF, 1993; LAKOFF; JOHNSON, 1980), ela estaria, então, "intrinsecamente presente nas concepções dos estudantes acerca da língua estrangeira aprendida" (MALTA, 2000; NARDI, 1999 apud CARVALHO; SOUZA, 2003, p. 32), cabendo ao professor, ou pesquisador, utilizá-la tanto como uma ferramenta pedagógica, quanto como um método para compreender a construção de um sentido abstrato a partir das experiências vivenciadas.

Uma vez que as experiências vivenciadas são a base para as construções metafóricas, ou seja, "a essência da metáfora emerge do experienciar uma coisa em termos de outra" (BARATA, 2014, p. 316), uma pesquisa que visa explorar e analisar metáforas envolve a identificação de experiências. Desse modo, concordamos com Barata (2014) que a utilização da Teoria da Metáfora Conceitual (LAKOFF; JOHNSON, 2002) juntamente com a identificação de experiências (MICCOLI, 2010; ARRUDA, 2014) tornam-se meios profícuos para a compreensão de aspectos inerentes ao ensino/aprendizagem de inglês, principalmente no que diz respeito às crenças de professores e estudantes com relação ao ensino/aprendizagem de inglês nas escolas regulares, bem como à sala de aula em si.

Desse modo, o objetivo central da presente pesquisa é identificar as metáforas de estudantes do ensino médio acerca de suas experiências de aprendizagem de inglês no ensino fundamental. Para atender a esse objetivo, partimos das seguintes perguntas:

1 Tradução livre de: As applied linguists, we are concerned with language use in real-life situations, particularly problematic ones.

2 Tradução livre de: [...] to reveal and understand underlying processes of language learning or use, and, perhaps to evaluate intervention in them. 
Como os alunos do ensino médio de uma escola pública de Belo Horizonte conceituam suas experiências de aprendizagem de inglês no ensino fundamental?

Até que ponto suas experiências apresentam semelhanças ou divergências?

O que as metáforas desses alunos nos dizem acerca do ensino/aprendizagem de inglês nas escolas públicas de Belo Horizonte?

\section{Referencial teórico}

Esta pesquisa se fundamenta nos pressupostos da Teoria da Metáfora Conceitual (LAKOFF; JOHNSON, 1980; LAKOFF, 1987; KÖVECSES, 2010), bem como nos trabalhos que concebem a experiência enquanto construto de análise (MICCOLI, 2010; ARRUDA, 2014).

A Teoria da Metáfora Conceitual tem como princípio fundamental a conceitualização do mundo por meio das metáforas. É o que fica evidenciado no seguinte excerto:

Nosso sistema conceitual tem um papel central ao definir as nossas realidades cotidianas. Se estivermos certos em sugerir que nosso sistema conceitual é amplamente metafórico, então o modo como pensamos, o que experienciamos, e o que fazemos todos os dias é muito mais uma questão de metáfora (LAKOFF; JOHNSON, 1980, p. 3$)^{3}$

A metáfora conceitual pode ser concebida como a interação entre dois domínios que são definidos como organizações coerentes da experiência (KÖVECSES, 2010). Ainda de acordo com o autor, as metáforas conceituais podem apresentar diferenças quanto a sua natureza. Há aquelas que se baseiam no conhecimento e outras que se baseiam em imagens. Nas primeiras, as estruturas básicas do conhecimento são mapeadas da fonte para o alvo. No segundo tipo de metáfora conceitual (image-schema metaphor), não há um mapeamento de elementos conceituais do conhecimento, mas, de elementos conceituais de esquemas de imagens. Nesse contexto, os domínios são imagens mentais, como é exemplificado na seguinte passagem de André Breton: "Minha mulher... cuja cintura é uma

3 Tradução livre de: Our conceptual system thus plays a central role in defining our everyday realities. If we are right in suggesting that our conceptual system is largely metaphorical, then the way we think, what we experience, and what we do every day is very much a matter of metaphor. 
ampulheta" (LAKOFF, 1993, p. 229), ${ }^{4}$ em que percebemos uma sobreposição da imagem de uma ampulheta na imagem da cintura de uma mulher pela semelhança de forma. Sendo assim, a metáfora é conceitual não pelas palavras e sim pelas imagens mentais.

É importante ressaltar a distinção entre metáforas estruturais e esquemas imagéticos (KÖVECSES, 2010, p. 43):

Mais importante para a discussão das metáforas de esquemas imagéticos é que elas mapeiam relativamente pouco da fonte para o alvo. Como o próprio nome implica, metáforas desse tipo têm domínios-fonte que possuem um esqueleto de esquema de imagens [...]. Em contrapartida, as metáforas estruturais são ricas em estruturas de conhecimento e fornecem um conjunto relativamente rico de mapeamentos entre a fonte e o alvo. ${ }^{5}$

Outra questão abordada pelo autor (KÖVECSES, 2010) diz respeito às expressões idiomáticas. Segundo ele, as expressões idiomáticas não devem ser vistas apenas como um conjunto de palavras que possuem um sentido especial, pois, grande parte delas tem como base metáforas, que possibilitam o mapeamento de dois domínios do conhecimento. É o que percebemos, por exemplo, na expressão "Ele estava cuspindo fogo", que pode ser caracterizada como uma manifestação da metáfora conceitual Raiva é Fogo e que nos permite, a partir do nosso sistema conceitual, usar o domínio-fonte "fogo" para falar do domínio-alvo "raiva".

Ainda no que diz respeito às imagens mentais, existe o entendimento de que a nossa capacidade mais básica de categorização é a responsável pela estruturação das nossas experiências (LAKOFF, 1987, p. 269-270). Ou seja, em termos gerais, nós temos uma capacidade de lidar com as estruturas dos objetos no mundo através da nossa percepção, da nossa função motora e da formação de imagens mentais, advindas de uma capacidade de conceitualização estruturada na experiência.

Desse modo, devido à centralidade da experiência como a principal responsável por estruturar nossas conceitualizações acerca do mundo que nos cerca, defendemos que, a partir da compreensão da experiência, podemos obter respostas sobre temas relacionados ao ensino, à aprendizagem e à sala de aula.

4 Tradução livre de: My wife... whose waist is an hourglass.

5 Tradução livre de: More important for the discussion of image-schema metaphors is that they map relatively little from source to target. As the name implies, metaphors of this kind have source domains that have skeletal image-schemas [...]. By contrast, structural metaphors are rich in knowledge structure and provide a relatively rich set of mappings between source and target. 


\section{Crenças e experiências no contexto do ensino/aprendizagem de inglês na escola regular}

Pesquisas acerca de problemas e insucessos com relação ao ensino/aprendizagem de inglês no contexto de escolas regulares - principalmente públicas - brasileiras têm sido recorrentes na literatura (COELHO, 2005; PAIVA, 1997; MOITA LOPES, 1996; BARCELOS, 1995, 2007; LIMA, 2011) e abordam a questão das crenças de professores e alunos com relação ao ensino/aprendizagem de inglês naquele contexto. Tais crenças corroboram o discurso e "alicerçam o paradigma" (ARRUDA, 2014, p. 7) de que não é possível aprender inglês na escola.

Ensino e aprendizagem podem ser concebidos como complexos, uma vez que são processos abertos a novas possibilidades, não são imutáveis, lineares e progressivos (PAIVA, 2006). E ainda são passíveis de limitações, são influenciados por conflitos que perpassam os campos institucionais, extrainstitucionais, individuais e emocionais. Tal complexidade com relação ao processo de ensino e aprendizagem torna-se ainda mais evidente quando se trata da sala de aula, onde nos deparamos com um mesmo espaço que é compartilhado por indivíduos diferentes, que foram moldados em diferentes ambientes culturais, econômicos, familiares e que trazem para esse ambiente em comum todas as suas crenças, seus valores, atitudes, suas expectativas, sucessos, fracassos. Um espaço que não existe no isolamento, ou seja, ele pertence a uma instituição de ensino (escola), a qual, por sua vez está inserida em um sistema educacional que se estende para além de seus muros.

É nesse contexto complexo que ocorre o "desafio" de ensinar e aprender em sala de aula (MICCOLI, 2010), no qual entram em cena fatores mais abrangentes como as políticas públicas e orientações curriculares, questões econômicas, regionais e também fatores mais localizados, que dizem respeito à instituição de ensino, à sala de aula, e aos seus principais personagens: professores, alunos e familiares desses alunos. Nesse sentido, concordamos com o pensamento da referida autora de que as pesquisas com o foco nas experiências podem ser impactantes ao promoverem uma transformação, não apenas no espaço da sala de aula em si, mas em todo o sistema educacional. Transformação esta que ocorrerá por meio da reflexão acerca daquilo que é experienciado.

$\mathrm{O}$ conceito de experiência em que nos apoiamos pode ser explicado no trecho a seguir: 
A experiência é um processo por ter a ver com relações, dinâmicas e circunstâncias vividas em um meio particular de interações na sala de aula, a qual ao ser narrada deixa de ser um acontecimento isolado ou do acaso. $\mathrm{O}$ processo reflexivo da narrativa oferece a oportunidade de ampliar o sentido dessa experiência e de definir ações para mudar e transformar seu sentido original bem como aquele que a vivenciou (MICCOLI, 2010, p. 29).

Miccoli (2010), ao lidar com experiências de professores em contextos particular e público, afirma que "todo estudante ou ex-estudante da Educação Básica, caso não tenha frequentado instituições particulares de ensino de línguas, caracteriza sua aprendizagem como inglês de colégio" (MICCOLI, 2010, p. 177). Tal aprendizagem (inglês de colégio) traz uma conotação negativa, e implica um conhecimento restrito de inglês, longe de ser aquele ensino que propicia ao aluno uma aprendizagem mais ampla e que envolva as quatro habilidades da língua.

Com relação às crenças, concordamos com o pensamento de que "as crenças se retroalimentam" (ARRUDA, 2014), ou seja, se as pessoas acreditarem que é impossível aprender inglês na escola, as suas ações serão direcionadas a obter esse resultado. Nesse sentido, as crenças sobre ensino/aprendizagem de línguas poderiam ser definidas como:

[...] uma forma de pensamento, construções da realidade, maneiras de ver e perceber o mundo e seus fenômenos, coconstruídas em nossas experiências resultantes de um processo interativo de interpretação e (re) significação. Como tal, crenças são sociais (mas também individuais) dinâmicas, contextuais e paradoxais (BARCELOS, 2006, p. 18).

Se pensarmos então que as crenças são construídas por meio do modo como vivenciamos a realidade, não seria o momento de começarmos a “construir' outras realidades por meio da investigação de novas experiências? Experiências que incentivem, que inspirem o surgimento de diferentes realidades? Até que ponto a crença de que não se aprende inglês na escola não reforça, ou, até mesmo, cria essa realidade?

Tais questionamentos são compartilhados por Barcelos (2011) quando indaga:

Que outras histórias sobre aprendizagem de línguas podemos contar? Que histórias diferentes podemos contar sobre aprendizagem de inglês na escola pública? Por que não temos narrativas de aprendizes bem-sucedidos, narrativas de professores 
que fazem a diferença, de alunos que aprenderam inglês na escola pública, e finalmente, de escolas públicas que fazem a diferença? (BARCELOS, 2011, p. 158.)

Sendo assim, reafirmamos que "a aprendizagem de línguas estrangeiras é uma possibilidade viável em sala de aula" (MICCOLI, 2010, p. 18) e reforçamos a necessidade de se conduzirem investigações acerca de experiências bem-sucedidas de aprendizagem de inglês no ensino regular, tanto no contexto público quanto no privado, para que se possa, a partir da reflexão, compreendê-las e, desse modo, contribuir para uma "mudança de paradigma da ineficiência do ensino de línguas na escola regular" (ARRUDA, 2014, p. 12) ${ }^{6}$ e para que discursos como esse do "inglês de colégio" (anteriormente mencionado) sejam desconstruídos.

\section{Metodologia}

A pesquisa apresentada neste artigo se insere no paradigma qualitativo, embora alguns dados quantitativos também sejam utilizados, configurando-se como uma pesquisa de natureza mista (DÖRNYEI, 2007).

Para a coleta de dados, foi utilizada uma atividade de reflexão (KRAMSCH, 2003) que visou compreender como os alunos conceitualizam seus processos de aprendizagem de inglês no ensino fundamental. Nessa atividade, os alunos deveriam completar duas frases utilizando metáforas:

1) Aprender inglês no Ensino Fundamental era (como)...

2) $\mathrm{Meu}(\mathrm{s})$ professor(es) de inglês no Ensino Fundamental era(m) (como)...

Ao refletir sobre o instrumento utilizado por Kramsch, poderia se pensar em analogias e não em metáforas, devido ao uso da palavra "como" nas proposições: "Aprender era como" e "Meu(s) professor $(e s)$ era $(m)$ como". Contudo, para a autora, como a metáfora é um construto cognitivo e não apenas um recurso estilístico, ela "pode subjazer, na superfície linguística, o que se apresenta como uma metáfora ou um símile" (KRAMSCH, 2003, p. 111); ${ }^{7}$ ou seja, “cognitivamente

6 Ao falar sobre experiências bem-sucedidas na aprendizagem, a autora refere-se "àquelas nas quais os estudantes e/ou professores relatam satisfação e resultado de aprendizagem de ILE (Inglês como Língua Estrangeira)" (ARRUDA, 2014, p. 12).

7 Tradução livre de: [...] it may underlie what, on the linguistic surface, looks like either a metaphor 
falando, uma metáfora pode subjazer um símile" (apud CAMERON, 1999, p. 12). ${ }^{8} \mathrm{O}$ importante é que se faça o mapeamento entre os domínios (fonte e alvo). Desse modo, se o participante afirma que aprender inglês no ensino fundamental era como estar em um deserto, ele está mapeando o domínio-fonte (deserto) no domínio-alvo (aprendizagem). Logo, para esse participante, a aprendizagem de inglês no ensino fundamental era um deserto.

A presente pesquisa foi realizada em agosto de 2015, em uma escola estadual de Belo Horizonte, e contou com a participação de alunos do $3^{\circ}$ ano do Ensino Médio (turno da manhã). A atividade reflexiva foi aplicada em 4 turmas somandose um total de 120 alunos que estavam presentes no dia da aplicação da atividade.

Para a análise do corpus, esse trabalho se apoiou na Teoria da Metáfora Conceitual (LAKOFF; JOHNSON, 1980), em (KRAMSCH, 2003) e no marco de referência das experiências (MICCOLI, 2010; ARRUDA, 2014). Primeiramente, as metáforas produzidas pelos alunos foram categorizadas após repetidas e minuciosas leituras realizadas por mim e em concordância com trabalhos já realizados por autores renomados no campo da Metáfora Conceitual e Linguística Aplicada, como os citados acima, com destaque para o trabalho que inspirou a presente pesquisa (KRAMSCH, 2003). A autora propõe duas abordagens para compreender o modo como os estudantes constroem suas crenças por meio de metáforas: uma que leva em conta como os pesquisadores processam metáforas explícitas produzidas pelos estudantes ao conceituar sua experiência de aprendizagem com a língua e outra que demonstra o modo como podemos processar metaforicamente os depoimentos biográficos dos estudantes. Para realizar o presente estudo, apoiamo-nos na primeira abordagem que visa compreender as metáforas explícitas produzidas pelos estudantes adotando um viés discursivo que tem como foco "compreender a construção metafórica no espaço da crença, que é em parte compartilhada e moldada pelos outros, e no qual vários possíveis cenários são retratados" (KRAMSCH, 2003, p. 116). ${ }^{9}$ Nesse sentido, as metáforas produzidas pelos alunos na atividade de reflexão puderam ser categorizadas, respeitando o mapeamento conceitual entre fonte e alvo, de acordo com as similaridades que apresentaram. Entretanto, houve uma dificuldade em mapear algumas delas, exatamente pelo fato de a construção metafórica possibilitar "vários cenários", e como consequência,

or a simile.

$8[\ldots]$ cognitively speaking, a metaphor may underlie a simile.

9 Tradução livre de: It focuses, rather, on the metaphoric construction of a belief space, that is in part shared and shaped by others, and in which various possible scenarios are acted out. 
várias interpretações. Desse modo, para que haja um maior rigor científico quanto à análise dos dados, detectamos a necessidade de realizar uma futura pesquisa complementar em que retomaremos a tarefa inicial aplicada no presente estudo, mas, contendo o pedido de que o estudante justifique, ou explique a razão do uso daquela metáfora.

Após a etapa de categorização das metáforas, estas foram quantificadas de acordo com o número de ocorrência que apresentaram. Finalmente, as metáforas foram categorizadas em "Experiências bem-sucedidas" e "Experiências de insucesso".

\section{Resultados e discussão}

No total, 110 alunos realizaram a atividade reflexiva. Do número total de frases completadas pelos alunos, verificamos que 84 delas continham expressões metafóricas com relação à aprendizagem e 79 continham expressões metafóricas com relação ao professor.

Pode-se notar, a partir da observação do GRÁF. 1, referente à quantificação das metáforas que remetiam às "Experiências bem-sucedidas" e às "Experiências de insucesso", um número de ocorrências substancialmente maior das últimas. De um total de 84 frases que continham expressões metafóricas acerca da aprendizagem, 50 estavam relacionadas às experiências de insucesso e apenas 12 remetiam às experiências bem-sucedidas. $\mathrm{O}$ mesmo ocorreu com relação ao professor. Nesse caso, de um total de 79 expressões metafóricas, 42 se referiam às experiências de insucesso e apenas 16 às experiências bem-sucedidas.

Esses dados reforçam as crenças relatadas nas pesquisas anteriormente citadas acerca do ensino e aprendizagem de inglês, principalmente a crença da sala de aula das escolas regulares como um espaço de não aprendizagem da língua. 
GRÁFICO 1 - Metáforas (professor e aprendizagem)

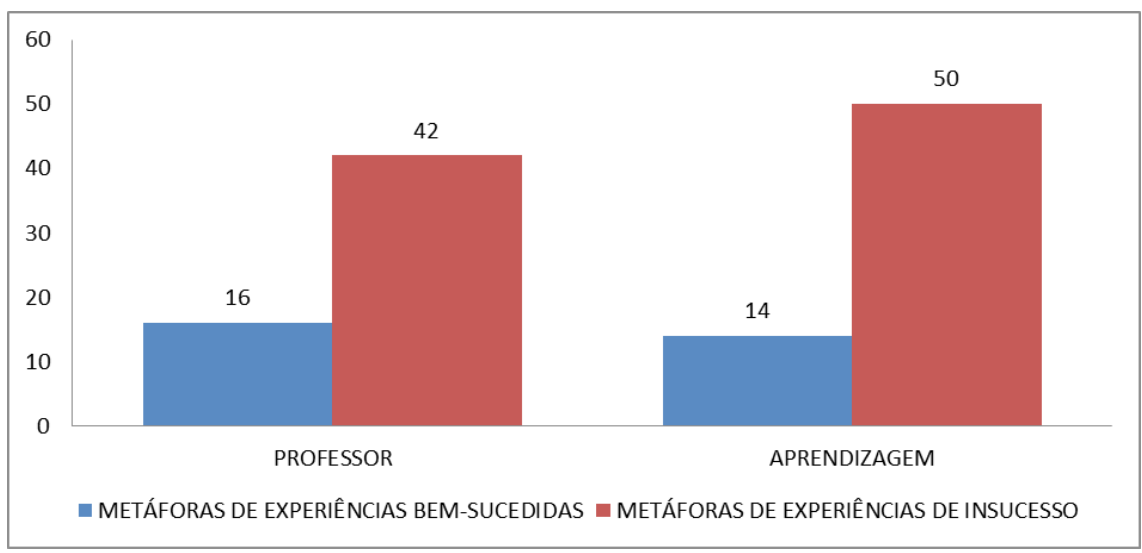

Fonte: Elaborado pela autora.

Algumas metáforas não foram inseridas no gráfico acima devido à dificuldade encontrada pela pesquisadora em fazer o mapeamento dos domínios, correlacionando-os com as "experiências bem-sucedidas" ou "experiências de insucesso", pois metáforas que se referem à aprendizagem como a de estar na hora do "recreio" e aquelas que se referem ao professor como "palhaço", embora, em um primeiro momento, possam sugerir algo com conotação positiva, podem, na verdade encobrir uma crítica àquele tipo de aprendizagem ou àquele tipo de professor. Os estudantes, ao usarem essas metáforas, podem também estar dizendo que não aprendiam nas aulas, visto que podemos mapear recreio com: várias pessoas falando ao mesmo, pessoas fazendo aquilo que querem, hora do intervalo em que não há mais o foco na aprendizagem. E ainda, como podemos afirmar que um estudante, ao falar que seu professor era como um "palhaço", está dizendo algo bom do seu professor? Pode-se fazer um mapeamento de "palhaço" como uma pessoa divertida, mas, também como alguém que "fala" e "faz palhaçadas". Desse modo, surge a indagação: até que ponto aquele professor "palhaço" contribuiu realmente para a aprendizagem de seu aluno? Como já argumentamos anteriormente, verificamos a necessidade de incluir em trabalhos futuros o item "justifique" nas respostas dos alunos, a fim de identificar as relações com as diferentes metáforas para que questionamentos como esse possam ser devidamente esclarecidos.

Com relação à recorrência das metáforas de insucesso sobre o professor (GRÁF. 2), nota-se um número maior (7) das mesmas, na categoria "metáfora 
do estranhamento", que retratam o professor como uma "figura estranha". Em seguida, na categoria "metáfora da falta de dinamismo" - que obteve 6 ocorrências - os professores foram vistos como "postes", ou como "tartarugas", ou seja, pessoas pouco dinâmicas no exercício da sua função. A categoria "metáfora da dificuldade na comunicação" foi a terceira mais recorrente (5). Aqui, os alunos produziram metáforas que remetiam à dificuldade de se comunicarem com seus professores, seja por meio da fala, seja da escrita. Outras categorias emergiram a partir da análise das metáforas acerca dos professores: "metáfora da repetição", "metáfora da falta de orientação", "metáfora da falta de pensamento crítico", "metáfora da raiva, passionalidade", "metáfora das experiências negativas" e "metáfora do autoritarismo".

GRÁFICO 2 - Metáforas de experiências de insucesso (professor)

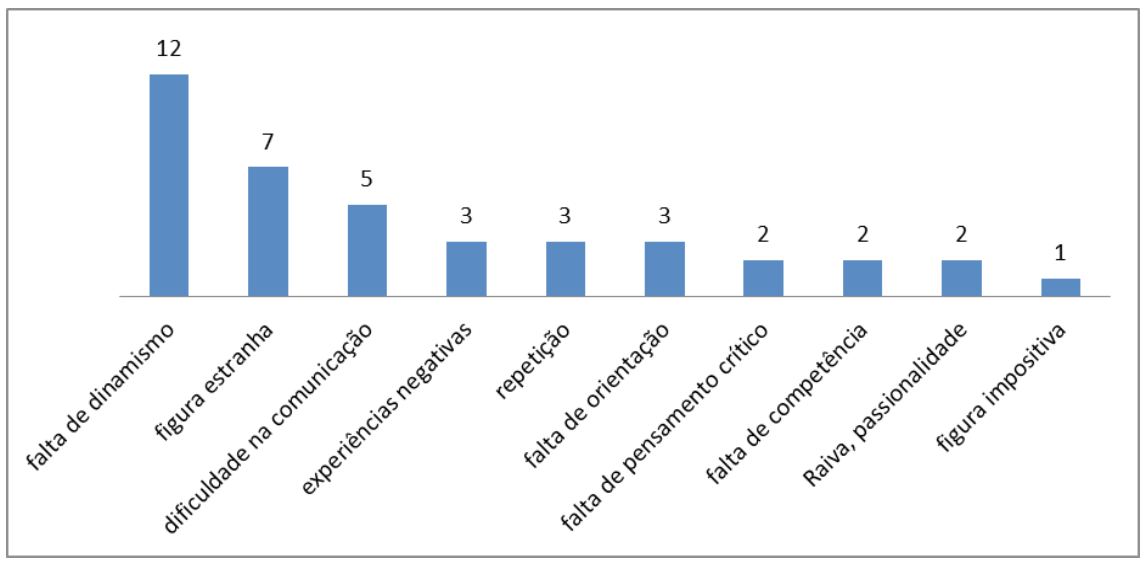

Fonte: Elaborado pela autora.

No que diz respeito às metáforas de experiências de insucesso acerca da aprendizagem de inglês no ensino fundamental, aquelas mais recorrentes se inserem na categoria "metáfora da repetição", em que os alunos conceituaram sua aprendizagem como algo repetitivo (21\%), seguida da categoria "metáfora da dificuldade" (18\%), em que a aprendizagem foi percebida como algo difícil. Três outras categorias obtiveram o mesmo índice de ocorrências (11\%): "metáfora da falta de orientação", em que os alunos se sentiam "perdidos" nas aulas, a "metáfora da falta de sentido/propósito", em que os alunos não viam propósito algum naquele tipo de aprendizado, ou seja, a aprendizagem era algo que não 
atendia aos seus interesses; e também a "metáfora da experiência negativa/ traumatizante", que deixou marcas na trajetória de aprendizagem daquele estudante o que, provavelmente, ainda traz implicações negativas no atual contexto de aprendizagem do mesmo. As demais categorias podem ser visualizadas no GRÁF. 3.

É interessante ressaltar que, na categoria "metáfora da repetição", quatro alunos mencionaram o "verbo to be", ou seja, eles conceituaram a aprendizagem de inglês como algo que se restringia ao "verbo to be". Isso nos mostra que, de todo o conteúdo ensinado, o "verbo to be" foi o mais marcante. Diante dessa constatação, pode-se chegar às seguintes interpretações: os alunos aprenderam apenas o "verbo to be" porque houve uma persistência do ensino desse conteúdo ao longo de todo o ensino fundamental ou, então, porque esse conteúdo foi realmente significativo para aqueles alunos. Levando em conta minha experiência profissional de doze anos como professora de inglês no ensino básico, arrisco-me a dizer que, possivelmente, a primeira interpretação é a mais aceitável. Esse mesmo pensamento é compartilhado por Arruda (2014) quando argumenta que quando se dá voz aos alunos, muitos deles se queixam de aprender um mesmo conteúdo gramatical ao longo dos vários anos de aprendizagem.

GRÁFICO 3 - Metáforas de experiências de insucesso (aprendizagem)

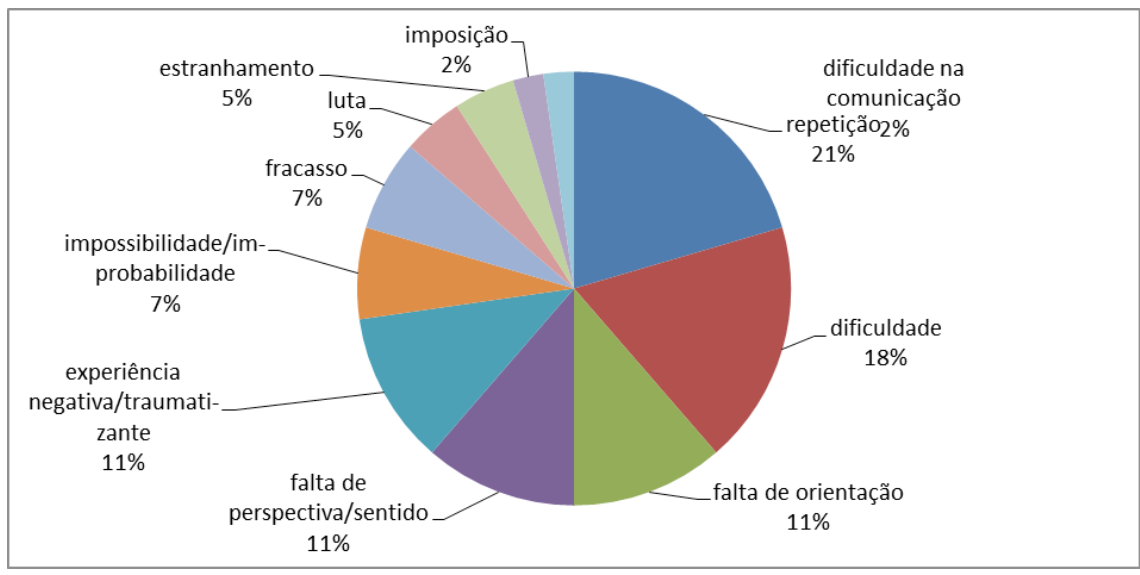

Fonte: Elaborado pela autora

Com relação às metáforas de experiências bem-sucedidas na aprendizagem (GRÁF. 4), em um total de 14 ocorrências, a categoria "metáfora da facilidade 
na aprendizagem" foi a que obteve um maior número de ocorrências (6). Em seguida, na categoria "metáfora da aprendizagem como algo inédito", 4 alunos conceituaram sua aprendizagem de inglês no ensino fundamental como algo diferente, inédito. Houve também 2 alunos que associaram sua aprendizagem de inglês às suas comidas favoritas ("aprendizagem é alimento"). Finalmente, as categorias "metáfora da aprendizagem como recompensa" e "metáfora da aprendizagem como algo essencial" obtiveram uma ocorrência cada uma delas .

GRÁFICO 4 - metáforas de experiências bem-sucedidas (aprendizagem).

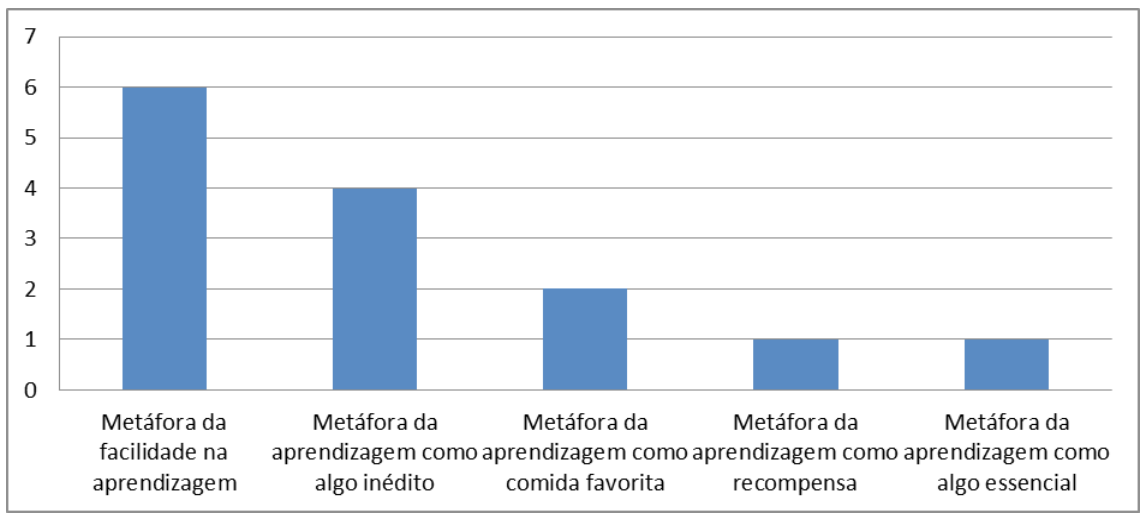

Fonte: Elaborado pela autora.

Com relação ao professor (GRÁF. 5), duas categorias de metáforas emergiram a partir da análise dos dados: "metáforas de atitudes do professor" e "metáforas das práticas do professor", com um número de ocorrências de 10 e 6 , respectivamente, em um total de 16. Nas metáforas desses alunos, os professores foram comparados a plantas ("pteridófitos sobreviventes no deserto", em que o professor, representado pela planta é percebido como uma pessoa forte, resistente e o "deserto" pode ser uma representação da sala de aula, da escola, ou até mesmo do sistema educacional em si, que não oferece "água", ou seja, as condições adequadas de trabalho como bons salários, incentivo e valorização à sua profissão); com a comida ("comer quando está com fome", que pode ser interpretada como a busca pela saciedade, em que o professor, figura que representa o conhecimento, é o responsável por "saciar a fome" de conhecimento dos seus alunos); com o "ar" e o "sol" (essenciais à vida) e ainda, como pessoas raras e valiosas como "diamantes". 
GRÁFICO 5 - metáforas de experiência bem-sucedidas (professor).

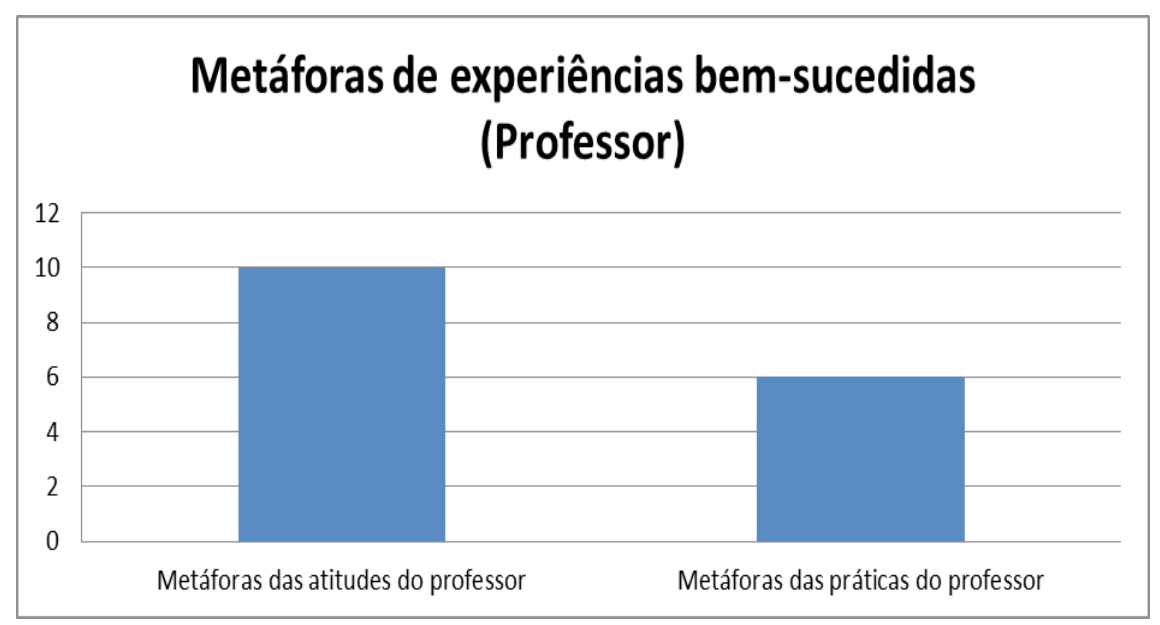

Fonte: Elaborado pela autora.

A identificação de metáforas de experiências bem-sucedidas corrobora os pensamentos de Miccoli (2010), Paiva (2011), Barcelos (2011), entre outros educadores, de que é possível aprender inglês na escola, mesmo que em um nível funcional de proficiência, considerando que ela se caracteriza como espaço "para conhecer e aprender uma língua estrangeira (LE)" (ARRUDA, 2014, p. 11). E ainda, é preciso haver mais registros de boas experiências em teses e dissertações (PAIVA, 2011), uma vez que a própria autora alega ter testemunhado bons trabalhos realizados por professores em escolas públicas de Belo Horizonte.

\section{Considerações finais}

Os dados apresentados neste estudo revelam que é inegável o fato de que as experiências de insucesso de aprendizagem de inglês na escola ainda se mostram mais numerosas do que as bem-sucedidas, o que vai ao encontro dos dados apontados por várias pesquisas que discutem a questão do ensino e aprendizagem de inglês no ensino regular. Tal evidência também reforça a crença da inviabilidade, do fracasso na aprendizagem de inglês nesse contexto. Dentre as metáforas de experiências de insucesso, os alunos conceituaram sua aprendizagem como algo repetitivo, difícil, sem sentido, como algo impossível, como uma experiência traumatizante, e isso certamente não pode ser ignorado. Tais experiências nos 
levam a refletir sobre como nós, enquanto professores, podemos rever nossas práticas visando melhorar o trabalho que realizamos em nossas salas de aula.

Entretanto, não basta constatar que os dados dessa pesquisa são condizentes com as crenças acerca dos problemas e insucessos com relação ao ensino e aprendizagem de inglês nas escolas. É preciso romper com elas, uma vez que “[...] assumir passivamente que a rede de ensino básico é incompetente para ensinar línguas é perpetuar o mito de que só as escolas de idiomas são capazes dessa tarefa" (PAIVA, 2000, p. 29).

Nesse sentido, propomos voltar o nosso olhar para as metáforas que remetem às experiências bem-sucedidas dos estudantes participantes do presente estudo. Isso não significa simplesmente ignorar os problemas e focar apenas no que está dando certo, e sim que precisamos dar visibilidade a trabalhos excelentes desenvolvidos nas escolas, os quais, muitas vezes, são ignorados pelos pesquisadores da área da linguística aplicada (PAIVA, 2011).

Dessa forma, vale indagar: o que as metáforas de experiências bemsucedidas produzidas pelos alunos nos dizem sobre a aprendizagem, bem como sobre os professores de inglês nas escolas regulares de Belo Horizonte? Elas retratam a aprendizagem de inglês como algo fácil, para alguns deles, como algo recompensador, algo inédito, diferente, agradável, como algo essencial. Elas retratam ainda os professores como pessoas raras e valiosas, como pessoas sábias, atenciosas, como um reflexo do que querem ser, como pessoas fortes. Diante disso, reiteramos que é preciso investigar que aprendizagem é essa que impactou positivamente a vida desses alunos. Que professores são esses, que, de certa forma, contribuíram para que essa experiência de aprendizagem bemsucedida fosse possível. A partir de uma investigação sobre experiências, pode-se compreender quais fatores contribuem para uma aprendizagem bem-sucedida, e as metáforas podem nos auxiliar nesse sentido, servindo como ponto de partida para essa compreensão.

Falar de experiências bem-sucedidas nos possibilita olhar para o ensino e aprendizagem de inglês na escola de outra maneira, para além de preconceitos e crenças, o que propiciará e acarretará mudanças profundas no nosso sistema educacional, quebrando o atual paradigma (ARRUDA, 2014) da impossibilidade de se aprender inglês nas escolas regulares brasileiras, sejam estas públicas ou privadas. 


\title{
The relevance of the metaphors as a conceptualization of experiences: a reflection about the English teaching/learning in the regular school
}

\begin{abstract}
-
Conceiving the metaphor as a means of conceptualizing the world from our daily experiences, the present study aims at identifying the metaphors made by high school students about their English learning when they were in the elementary school. The research was conducted in 2015 using qualitative and quantitative data. The corpus analysis of the present work was made under the Conceptual Metaphor Theory along the lines of studies carried out by renowned authors in this field and according to the experiences referential framework. The results show that despite the great number of students' metaphors about their experiences of failure regarding the learning and the teacher, we could also identify metaphors about experiences of success, which indicates a rupture with the structured ways of thinking about English learning in the regular school and underpins the thesis that it is possible to learn English in this context.
\end{abstract}

Keywords: Metaphors. Experiences. English teaching/learning. Regular school.

\section{Referências}

ARRUDA, Climene Fernandes Brito. É preciso propiciar a aprendizagem de inglês na escola: experiências bem-sucedidas para investir em uma mudança de paradigma. Tese (Doutorado em Estudos Linguísticos) - Faculdade de Letras da Universidade Federal de Minas Gerais, Belo Horizonte, 2014. Disponível em: $<$ http://www.bibliotecadigital.ufmg.br/ dspace/handle/1843/MGSS-9MQPBD>. Acesso em: 18 ago. 2015.

BARATA, Maria Clara Carelli Magalhães. Modelos de avaliação experienciados e idealizados - Experiências, Metáforas e Crenças de alunas e professoras em formação. In: MICCOLI, Laura (Org.). Pesquisa experiencial em contextos de aprendizagem: uma abordagem em evolução. Campinas, SP: Pontes, 2014. p. 315-348.

BARCELOS, Ana Maria Ferreira. A cultura de aprender língua estrangeira (inglês) de alunos de Letras. 1995. 140 f. Dissertação (Mestrado em Lingüística Aplicada) - IEL, UNICAMP, Campinas, 1995. Disponível em: <http://www. bibliotecadigital.unicamp.br/ document/?code $=$ vtls000099725 $>$. Acesso em: 8 set. 2015. 
BARCELOS, Ana Maria Ferreira; VIEIRA-ABRAHÃO, Maria Helena (Org.). Crenças e Ensino de Línguas: foco no professor, no aluno e na formação de professores. Campinas, SP: Pontes, 2006.

BARCELOS, Ana Maria Ferreira. Crenças sobre ensino e aprendizagem de línguas: reflexões de uma década de pesquisa no Brasil. In: ALVAREZ, Maria Luíza O.; SILVA, Kleber A. da (Org.). Lingüística Aplicada: múltiplos olhares. Campinas: Pontes, 2007. p. 27-69.

BARCELOS, Ana Maria Ferreira. Lugares (im)possíveis de se aprender inglês no Brasil: crenças sobre aprendizagem de inglês em uma narrativa. In: LIMA Diógenes Cândido de (Org.). Inglês em escolas públicas não funciona? São Paulo: Parábola, 2011. p. 147-158.

CAMERON, Lynne. Operationalising 'metaphor' for applied linguistic research. In: CAMERON, Lynne; LOW, Graham (Org.). Researching and Applying Metaphor. Cambridge: Cambridge University Press, 1999. p. 3-28.

CARVALHO, Maurício Brito de; SOUZA, Ana Cláudia de. As metáforas e sua relevância no processo de ensino-aprendizagem de língua estrangeira. Fragmentos, Florianópolis, v. 24, p. 29-44, jan./jun. 2003. Disponível em: <file://C:/Users/ Micro/Downloads/7657-23010-1-PB.pdf>. Acesso em: 21 ago. 2015.

COELHO, Hilda Simone Henriques. "É possível aprender inglês em escolas públicas?" Crenças de professores e alunos sobre o ensino de inglês em escolas públicas. 2005. 140 f. Dissertação (Mestrado) - Programa de Pós-graduação em Linguística Aplicada, FALE - UFMG/ Belo Horizonte, 2005.

CORTAZZI, Martin; JIN, Lixian. Bridges to learning: Metaphors of teaching, learning and language. In: CAMERON, Lynne; LOW, Andrew (Org.). Researching and Applying Metaphor. Cambridge: Cambridge University Press, 1999. p. 149176.

DÖRNYEI, Zoltán. Mixed methods research: purpose and design. In: DÖRNYEI, Zoltán. Research methods in applied linguistics. Oxford: Oxford University Press, 2007. p. 163-175.

GOMES JUNIOR, Ronaldo Corrêa. Metáforas na rede: mapeamentos conceituais de estudantes universitários sobre aprendizagem de inglês. 2011. 115 f. Dissertação (Mestrado em Linguística Aplicada) - Programa de Pós-graduação em Estudos Linguísticos da Faculdade de Letras/UFMG, Universidade Federal de Minas Gerais, Belo Horizonte, 2011. Disponível em: <http://www.bibliotecadigital. ufmg.br/dspace/handle/1843/LETR-8SSUJY>. Acesso em: 3 ago. 2015. 
KÖVECSES, Zoltán. Metaphor: a practical introduction. $2^{\text {nd }}$ ed. Oxford: Oxford University Press, 2010.

KRAMSCH, Claire. Metaphor and the Subjective Construction of Beliefs. In: KALAJA, Paula; BARCELOS, Ana Maria Ferreira (Ed.). Beliefs about SLA: New Research Approaches. Dordrecht: Kluwer Academic Publishers, 2003. p. 109-128.

LAKOFF, George; JOHNSON, Mark. Metaphors we live by. Chicago: Chicago University Press, 1980.

LAKOFF, George; JOHNSON, Mark. Metáforas da vida cotidiana. Coordenação da tradução: Mara Sophia Zanotto. Campinas, SP: Mercado de Letras, 2002. 360 p. Original publicado em 1980.

LAKOFF, George. Women, fire, and dangerous things. Chicago: Chicago University Press, 1987.

LAKOFF, George. The contemporary theory of metaphor. In: ORTONY, Andrew. Metaphor and thought. Cambridge: Cambridge University Press, 1993. p. 202251.

LIMA, Diógenes Cândido de; LEFFA, Vilson J. Inglês em escolas públicas não funciona? Uma questão, múltiplos olhares. São Paulo: Parábola, 2011.

MALTA, Jacy Castro. O desenvolvimento da metacognição da metáfora: uma experiência de ensino. 2000. 141 f. Dissertação (Mestrado em Letras) Pós-Graduação em Letras/Linguística, Universidade Federal de Santa Catarina, Florianópolis, 2000.

MICCOLI, Laura. Ensino e aprendizagem de inglês: experiências, desafios e possibilidades. Campinas: Pontes, 2010.

MOITA LOPES, Luiz Paulo. "Eles não aprendem português quanto mais inglês". A ideologia da falta de aptidão para aprender línguas estrangeiras em alunos da escola pública. In: MOITA LOPES, Luiz Paulo (Org.). Oficina de lingüística aplicada: a natureza social e educacional dos processos de ensino/aprendizagem de línguas. Campinas, SP: Mercado de Letras, 1996. p. 63-80.

NARDI, I. A metáfora na leitura como evento social: instrumentos do pensar a Biblioteconomia do futuro. 1999. 254 f. Tese (Doutorado em Ciências Humanas) - Pós-Graduação em Linguística Aplicada e Estudos da Linguagem. Pontifícia Universidade Católica de São Paulo, São Paulo, 1999. 
PAIVA, Vera Lúcia Menezes de Oliveira e. A identidade do professor de inglês. APLIEMGE: Ensino e Pesquisa. Uberlândia, APLIEMGE/FAPEMIG, n. 1, p. 9-17, 1997. Disponível em: <http://www.veramenezes.com/identidade.htm>. Acesso em: 12 maio 2015.

PAIVA, Vera Lúcia Menezes de Oliveira e. O lugar da leitura na aula de língua estrangeira. Vertentes, n. 16, p. 24-29, jul./dez. 2000. Disponível em: <www. veramenezes.com>. Acesso em: 22 abr. 2004.

PAIVA, Vera Lúcia Menezes de Oliveira e. Autonomia e complexidade. Linguagem e Ensino, v. 9, n. 1, p. 77-127, 2006.

PAIVA, Vera Lúcia Menezes de Oliveira e. Ilusão, aquisição ou participação. In: LIMA, Diógenes Cândido de (Org.). Inglês em escolas públicas não funciona: uma questão de múltiplos olhares. São Paulo: Parábola, 2011, p. 33-46. Disponível em: <www.veramenezes.com>. Acesso em: 20 set. 2015.

Recebido em 17/03/2016.

Aceito em 05/07/2016. 